\title{
Identifikasi Sistem Panas Bumi Daerah Cangar, Jawa Timur menggunakan Metode Magnetotelurik
}

\begin{tabular}{l}
\hline Received \\
23 Oktober 2017 \\
Revised \\
30 Desember 2017 \\
Accepted for Publication \\
30 Desember 2017 \\
Published \\
10 Januari 2018 \\
\hline
\end{tabular}

\author{
Rahmawati $^{*}$, S Maryanto ${ }^{2}$ dan A Susilo
}

Program Pascasarjana Ilmu Fisika, Fakultas MIPA, Universitas Brawijaya, Jl. Veteran, Malang, 65145, Indonesia

Jurusan Fisika, Fakultas MIPA, Universitas Brawijaya, Jl. Veteran, Malang, 65145, Indonesia

"E-mail: rahmawati@student.ub.ac.id

\begin{abstract}
The research has been done in Cangar area of complex Mt.Arjuno-Welirang, East Java. This research using magnetotelluric method. The purpose of this research is to identify the geothermal system of research area based on its resistivity value. Acquisition of magnetotelluric data done in 11 point with spaces 70 meters up to 150 meters. Magnetotelluric measurement points is divided into 5 profile. Based on the result of data processing given range resisitivity value in research area between $4 \Omega$.m up to $2000 \Omega$.m. The result of modeling geothermal system in Cangar indicated of caprock ( $\leq 21 \Omega . \mathrm{m})$, reservoir $(21 \Omega . m-167 \Omega . m)$ and a heat source $(\geq 167 \Omega . m)$. Geothermal Cangar is controlled by Cangar fault.
\end{abstract}

Keywords: magnetotelluric, resistivity, geothermal, Cangar

\begin{abstract}
Abstrak
Penelitian mengenai identifikasi sistem panas bumi telah dilakukan di daerah Cangar kompleks Gunung Arjuno-Welirang, Jawa Timur. Metode yang digunakan adalah metode magnetotelurik. Penelitian ini bertujuan untuk mengetahui persebaran resistivitas sehingga dapat diketahui sistem panas bumi yang ada di daerah penelitian. Akusisi data magnetotelurik dilakukan sebanyak 11 titik dengan spasi 70 meter sampai 150 meter yang terbagi menjadi 5 lintasan. Berdasarkan hasil pengolahan data magnetotelurik diperoleh rentang nilai resistivitas berkisar antara $4 \Omega . m-2000 \Omega$.m. Hasil pemodelan menunjukkan bahwa sistem panas bumi di daerah Cangar terdiri dari lapisan penudung $(\leq 21 \Omega$.m), lapisan reservoar $(21 \Omega . m-167 \Omega . m)$ dan lapisan sumber panas ( $\geq 167 \Omega . m)$. Panas bumi Cangar diduga dikontrol oleh patahan Cangar.

Kata Kunci: magnetotelurik, resistivitas, panas bumi, Cangar
\end{abstract}




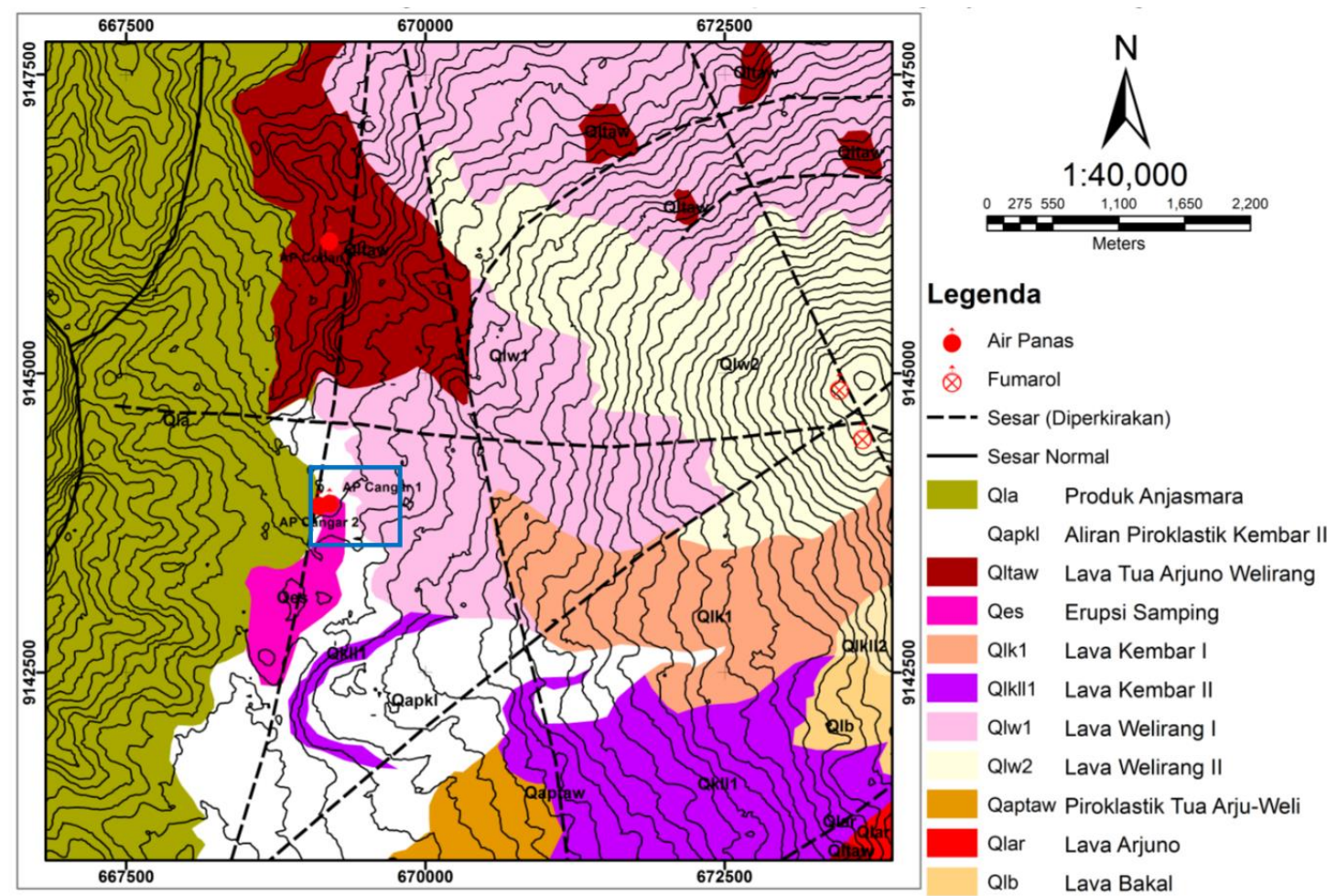

Gambar 1. Peta Geologi Daerah Panas Bumi Kompleks Gunung Arjuna-Welirang dan Lokasi Penelitian (modifikasi dari [4])

Kompleks Gunung Arjuno-Welirang merupakan salah satu daerah yang memiliki potensi panas bumi di Jawa Timur. Estimasi energi panas bumi di kompleks Arjuno-Welirang sebesar $280 \mathrm{MWe}$ [4]. Manifestasi panas bumi yang berada di kompleks Arjuno-Welirang salah satunya berupa mata air panas yang berada di Cangar. Secara geologi kompleks Arjuno-Welirang didominasi oleh batuan vulkanik kuarter, lava dan piroklastik [5]. Geologi daerah Cangar merupakan erupsi samping dari kompleks Gunung Arjuno-Welirang, lava Welirang I, aliran piroklastik Kembar I dan merupakan produk Anjasmara [6] (Gambar 1). Terdapat juga patahan yaitu patahan Cangar, diduga patahan tersebut sebagai faktor pengendali keberadaan air panas Cangar [7].

Sistem panas bumi memiliki tiga elemen penting yaitu sumber panas, reservoar dan fluida pembawa panas. Sumber panas dapat berupa intrusi magma yang memiliki temperatur sangat tinggi $\left(>600^{\circ} \mathrm{C}\right)$ dengan kedalaman sekitar $5 \mathrm{~km}-10 \mathrm{~km}$. Reservoar tersusun atas batuan yang bersifat permeabel. Reservoar merupakan tempat terakumulasinya fluida pembawa panas dan dilingkupi oleh lapisan penudung (cap rock). Sedangkan fluida panas bumi dapat berupa air maupun uap [8].

Beberapa penelitian yang pernah dilakukan di daerah Cangar yaitu menggunakan metode magnetik dan metode geolistrik. Berdasarkan hasil penelitian dari metode magnetik diperoleh bahwa terdapat anomali rendah yaitu $-1.000 \mathrm{nT}$, yang ditunjukkan dengan suseptibilitas rendah pula. Nilai suseptibilitas rendah menandakan adanya potensi panas bumi [9]. Berdasarkan penelitian dari metode geolistrik terdapat nilai resistivitas $\leq 10 \Omega$.m yang diduga merupakan lapisan pembawa fluida panas. Selain itu juga teridentifikasi adanya retakan di sekitar sumber panas mata air yang diduga sebagai media aliran air panas untuk keluar ke permukaan. Keberadaan panas bumi di daerah Cangar ditandai oleh mata air panas yang tersebar di dekat kolam pemandian [10]. Metode geolistrik sensitif dalam mendeteksi keberadaan air panas namun memiliki penetrasi dangkal [11].

Solusi yang ditawarkan dalam penelitian ini adalah menggunakan metode magnetotelurik. Metode magnetotelurik merupakan salah satu metode geofisika non seismik yang bersifat pasif, yang memanfaatkan gelombang elektromagnetik. Medan elektromagnetik ketika menembus bumi (bumi 
berperan sebagai konduktor) menghasilkan arus (arus telurik). Arus yang terinduksi tersebut menghasilkan medan magnet sekunder [12]. Persamaan diferensial yang mendasar untuk menjelaskan perilaku gelombang elektromagnetik dijelaskan pada persamaan Maxwell [13]:

$$
\begin{aligned}
& \nabla \cdot \mathrm{E}=\frac{\rho}{\varepsilon} \\
& \nabla \cdot \mathrm{B}=0 \\
& \nabla \times \mathrm{E}=-\frac{\partial \mathrm{B}}{\partial t} \\
& \nabla \times \mathrm{H}=\sigma \mathrm{E}+\varepsilon \frac{\partial \mathrm{E}}{\partial t}
\end{aligned}
$$

Medan listrik dan medan magnetik di bumi dapat dinyatakan sebagai berikut:

$$
\begin{aligned}
& E_{x}=E_{0} e^{-i \omega t} e^{-k z} \\
& H_{x}=\frac{1}{i \omega \mu_{0}} E_{0} e^{-i \omega t} e^{-k z}
\end{aligned}
$$

Medan magnetik yang terukur di permukaan bumi berasal dari sumber sinyal alami baik dalam maupun luar bumi [12]. Metode magnetotelurik banyak digunakan untuk menentukan distribusi resistivitas, mendeteksi anomali konduktif, dan penargetan lokasi sumur potensial di daerah panas bumi [14].

Metode magnetotelurik mampu menggambarkan sistem panas bumi secara detail karena memiliki penetrasi yang dalam. Kemampuan penetrasi yang dihasilkan dari metode magnetotelurik yaitu mulai dari beberapa puluh meter sampai ratusan kilometer [12]. Berdasarkan [8] diketahui bahwa lapisan sumber panas berada di kedalaman $5 \mathrm{~km}-10 \mathrm{~km}$, sehingga perlu metode yang dapat mengidentifikasi keberadaan lapisan sumber panas tersebut. Sedangkan berdasarkan dua metode penelitian sebelumnya, belum mampu menggambarkan sistem panas bumi secara detail. Hal tersebut dikarenakan kemampuan penetrasi yang dangkal. Sehingga metode magnetotelurik ini dianggap tepat digunakan untuk mengidentifikasi sistem panas bumi dibandingkan dengan metode yang sebelumnya.

\section{Metode Penelitian}

\subsection{Akusisi Data}

Akusisi data magnetotelurik dilakukan di sekitar pemandian air panas Cangar dan agrotechno park UB yang berada di desa Tulungrejo, Kecamatan Bumiaji, Kota Batu. Akusisi data di lakukan pada bulan Juli 2017. Titik pengukuran mt berjumlah11 titik dengan spasi antar titik yaitu 70 meter - 150 meter (Gambar 2). 


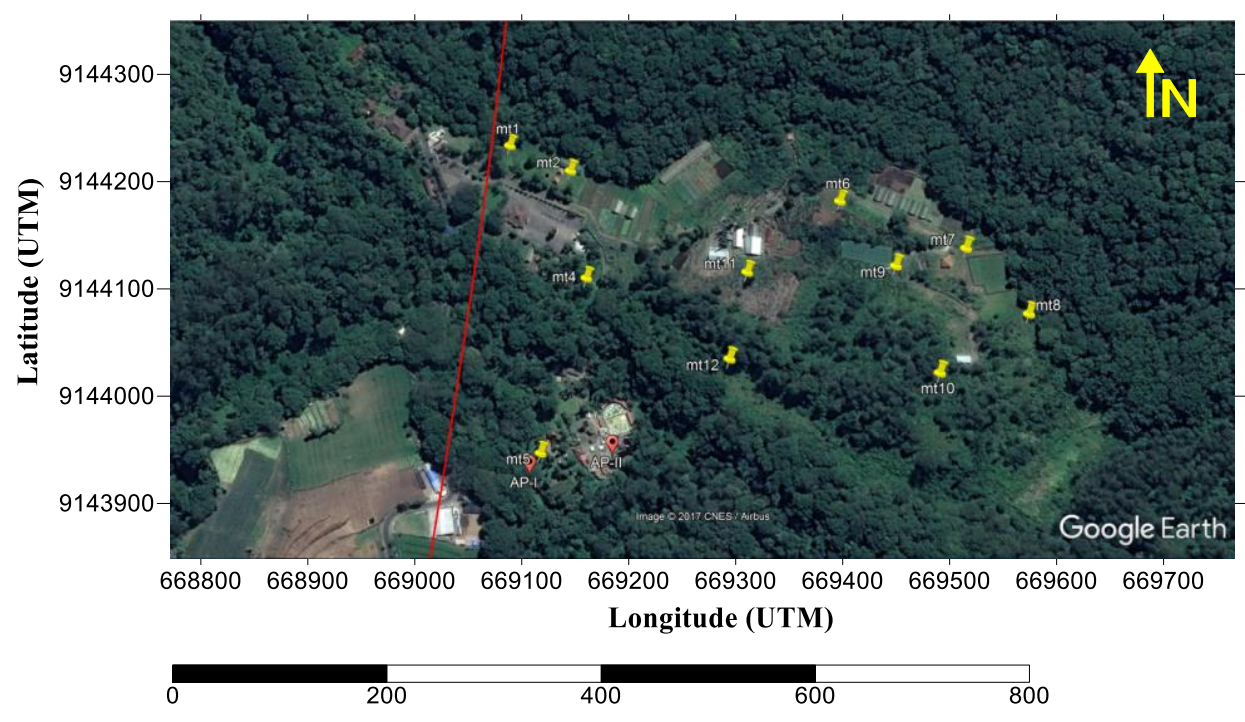

Gambar 2. Desain Survei Penelitian

Alat magnetotelurik yang digunakan pada penelitian ini yaitu Metronix ADU-07e. Konfigurasi akusisi data magnetotelurik pada umumnya terdiri dari empat porous pot dan tiga koil. Porous pot berperan sebagai sensor medan listrik $\left(E_{x}\right.$ dan $\left.E_{y}\right)$ yang ditanam saling tegak lurus. Porous pot $E_{x}$ ditanam pada arah utara-selatan dan porous pot $E_{y}$ pada arah timur-barat. Koil berperan sebagai sensor medan magnet $\left(H_{x}, H_{y}\right.$ dan $\left.H_{z}\right)$ yang ditanam pada kuadran yang berbeda. Koil $H_{x}$ dan $H_{y}$ saling tegak lurus dan ditanam secara horizontal sedangkan untuk koil $H_{z}$ ditanam secara vertikal. Koil $H_{x}$ ditanam pada arah utara-selatan sedangkan koil $H_{y}$ ditanam pada arah timur-barat. Selain itu dipasang juga elektroda dan GPS yang diletakkan dekat control unit, elektroda berfungsi sebagai ground.

Sebelum dilakukan akusisi data, terlebih dahulu alat dikalibrasi (selftest) selama \pm 30 menit. Sampling frekuensi yang digunakan yaitu $65 \mathrm{kHz}$ (frekuensi tinggi), $4 \mathrm{kHz}$ (frekuensi sedang) dan 128 $\mathrm{Hz}$ (frekuensi rendah) dengan waktu perekaman data selama 7 jam. Digunakan tiga sampling frekuensi yang berbeda dikarenakan setiap frekuensi memiliki tingkat penetrasi yang berbeda-beda. Hal ini sesuai dengan persamaan skin depth [13], yaitu:

$$
\delta \approx 530 \sqrt{\frac{\rho}{f}}
$$

Pada persamaan (7) menunjukkan bahwa skin depth bergantung pada dua parameter yaitu resisitivitas dari medium dan frekuensi gelombang. Skin depth menurun terhadap menurunnya resistivitas dan meningkatnya frekuensi. Sehingga dari ketiga sampling frekuensi yang digunakan tersebut akan menghasilkan tingkat penetrasi yang berbeda berdasarkan frekuensi yang digunakan. Frekuensi tinggi menghasilkan penetrasi dangkal, frekuensi sedang menghasilkan penetrasi sedang dan frekuensi rendah menghasilkan penetrasi dalam.

\subsection{Pengolahan Data}

Data magnetotelurik yang terekam merupakan data mentah dalam domain waktu. Sehingga perlu dilakukan transformasi data dari domain waktu ke dalam domain frekuensi. Pada metode magnetotelurik, transformasi Fourier banyak digunakan untuk mengubah deret waktu $E_{x}(t), B_{y}(t)$ kedalam domain frekuensi. Transformasi Fourier hanya dapat digunakan pada domain space atau waktu yang merupakan fungsi kontinyu [12]. Transformasi data dilakukan agar data lebih mudah dianalisis. Hasil dari transformasi Fourier diperoleh resistivitas semu dan fase. 
Persamaan transformasi Fourier dari domain waktu $x(t)$ ke dalam domain frekuensi $x(f)$ data dilihat pada persamaan di bawah ini [15]:

$$
x(f)=\int_{-\infty}^{\infty} x(t) e^{-i 2 \pi f t} d t
$$

Setelah diperoleh resistivitas semu dan fase dalam domain frekuensi, kemudian dilakukan tahap proses pemodelan 2D inversi. Inversi bertujuan untuk mencari model yang paling halus yaitu model yang sesuai dengan data. Dilakukan pencocokan kurva perhitungan (matematika) dengan data lapangan, untuk memperoleh distribusi parameter fisis yang belum diketahui [13]. Hasil dari pemodelan 2D inversi diperoleh distribusi resistivitas terhadap kedalaman dalam bentuk kontur, yang dianalisis pada interpretasi data.

\section{Hasil dan Pembahasan}

Kontur daerah penelitian berkisar pada elevasi 1600 mdpl - 1670 mdpl, pada Gambar 3 terlihat bahwa daerah pada arah barat memiliki elevasi yang lebih rendah dibandingkan dengan daerah pada arah timur.

Hasil model 2D inversi berupa penampang resistivitas bawah permukaan terhadap kedalaman. Model penampang setiap lintasan dapat dilihat pada Gambar 4 sampai Gambar 8. Kontur resistivitas untuk semua lintasan merupakan inversi menggunakan $\tau=5, \alpha=1$, dengan iterasi 150 kali dan diperoleh RMS error kurang dari 10\%.

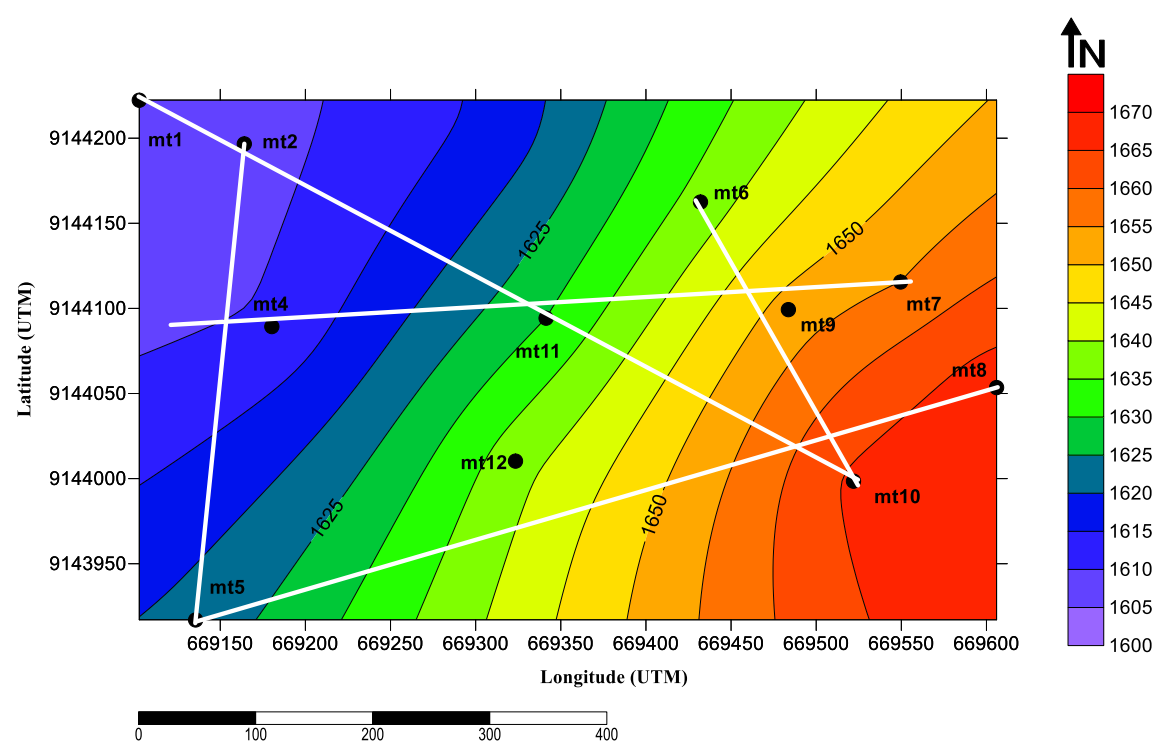

Gambar 3. Kontur Elevasi Daerah penelitian 


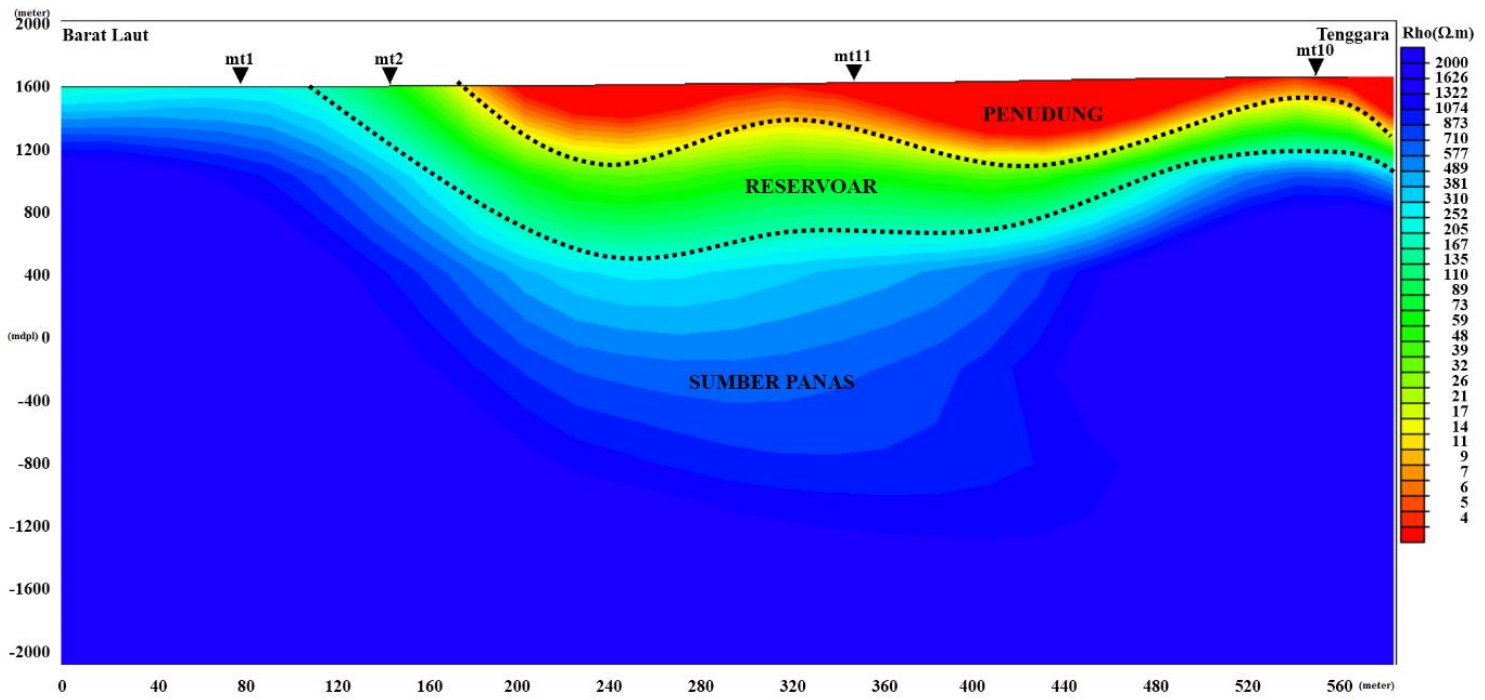

Gambar 4. Model Penampang 2D Lintasan 1

Model penampang lintasan 1 (Gambar 4) terdiri dari titik MT1, MT2, MT11 dan MT10. Pemilihan lintasan 1 ini disesuaikan dengan arah sayatan dari penelitian sebelumnya (metode magnetik) yaitu arah barat laut ke arah tenggara. Berdasarkan penampang lintasan 1, teridentifikasi adanya lapisan yang memiliki nilai resistivitas rendah $(\leq 21 \Omega . \mathrm{m})$ yang berada di permukaan sampai kedalaman 1300 meter. Lapisan dengan nilai resitivitas tersebut ditandai dengan lapisan yang berwarna merah. Terdapat terobosan nilai resistivitas sedang (21 $\Omega . m-167 \Omega . m)$ dan tinggi ( $\geq 167$ $\Omega . m)$ disekitar titik MT1 dan MT2 yang ditunjukkan oleh warna hijau dan biru. Berdasarkan peta geologi terdapat patahan Cangar di dekat titik MT1 dan MT2, sehingga menyebabkan tingginya resistivitas di sekitar titik tersebut.

Model penampang lintasan 2 (Gambar 5) terdiri dari MT2, MT4 dan MT5. Alasan pemilihan lintasan 2 dikarenakan searah dengan patahan Cangar. Hasil dari model penampang pada lintasan 2 juga diperoleh adanya lapisan yang memiliki nilai resistivitas rendah $(\leq 21 \Omega . \mathrm{m})$ yang berada di permukaan sampai kedalaman 400 meter. Lapisan dengan nilai resistivitas rendah ini lebih tebal dibandingkan pada lintasan 1 . Pada lintasan ini juga teridentifikasi adanya lapisan yang memiliki nilai

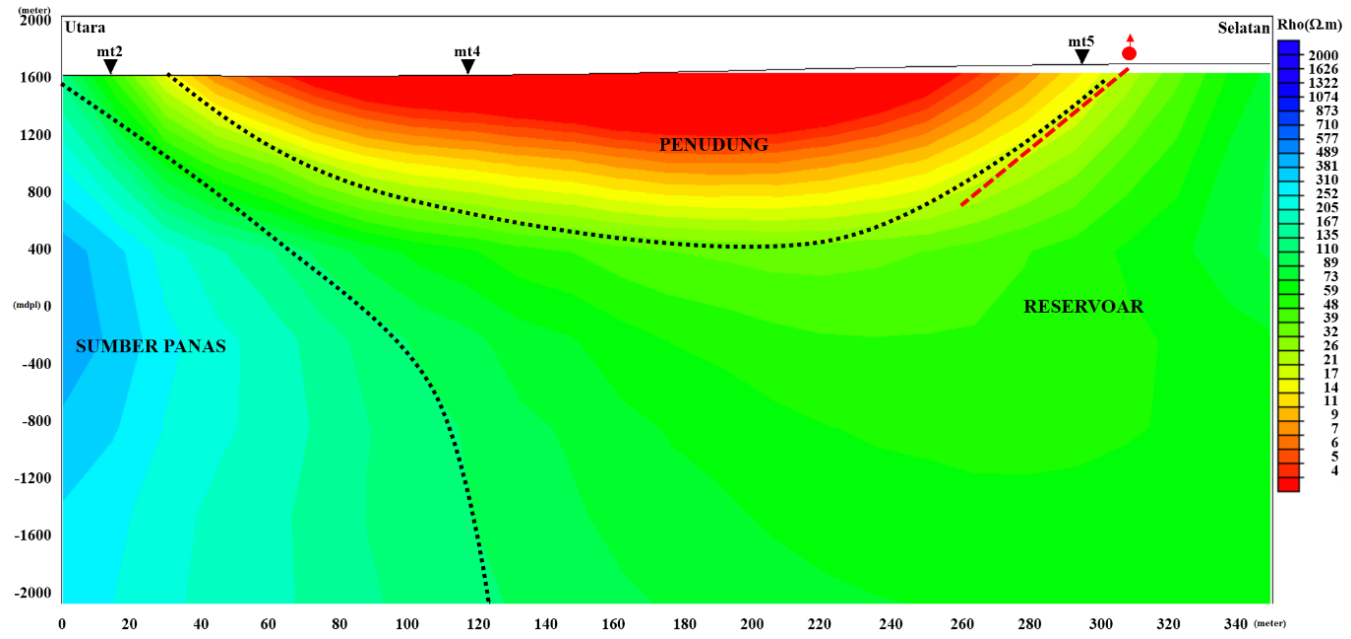

Gambar 5. Model Penampang 2D Lintasan 2 
resistivitas sedang (21 $\Omega . m-167 \Omega . m$ ), yang muncul di permukaan dan semakin menebal ke arah selatan. Di bawah lapisan resisitivitas sedang tersebut, tepatnya di sekitar titik MT2 arah utara terdapat lapisan dengan nilai reisitivitas tinggi $(\geq 167 \Omega$.m). Lintasan 1 dan lintasan 2 saling berpotongan pada titik MT2 sehingga terdapat kesesuaian hasil model penampang. Di sekitar titik MT5 yaitu di arah selatan terdapat manifestasi air panas, manifestasi air panas tersebut muncul ke permukaan diduga berasal dari retakan batuan. Retakan tersebut diduga berkaitan dengan adanya patahan Cangar yang menyebabkan fluida di dalam reservoar muncul ke permukaan.

Model penampang untuk lintasan 3 dapat dilihat pada Gambar 6. Lintasan 3 terdiri dari titik MT5, MT12, MT10 dan MT8. Pemilihan arah lintasan 3 tersebut juga disesuaikan dengan arah sayatan dari penelitian sebelumnya (metode magnetik) yaitu arah barat-timur. Pada penampang lintasan 3 teridentifikasi lapisan yang memiliki nilai resitivitas rendah $(\leq 21 \Omega . \mathrm{m})$ yang hanya berada di arah barat daya dan timur laut. Lapisan ini muncul di permukaan sampai pada kedalaman 1000 meter, yang ketebalannya cukup tipis dibandingkan pada lintasan sebelumnya. Lintasan 3 juga berpotongan dengan lintasan 2 pada titik MT5. Hasilnya memiliki kesesuaian yaitu terdapat terobosan nilai resistivitas sedang (21 $\Omega . m-167 \Omega . m$ ) pada titik MT5, dimana diketahui bahwa di sekitar titik MT5 ini terdapat manifestasi air panas yang diduga berasal dari retakan batuan yang disebabkan oleh patahan Cangar. Pada penampang ini juga teridentifikasi adanya lapisan yang memiliki nilai resistivitas tinggi ( $\geq 167 \Omega . m$ ) di permukaan. Di duga di sekitar titik MT5 dan MT12 batuan yang mendominasi yaitu batuan beku. Batuan beku tersebut berasal dari pembekuan dari gunung ArjunoWelirang [9]. Selain itu juga diketahui bahwa sepanjang titik MT5 ke titik MT12 dilewati kolam pemandian air panas Cangar dan sungai, yang diduga terdapat retakan-retakan batuan sehingga menyebabkan tingginya nilai resisitivitas di daerah tersebut.

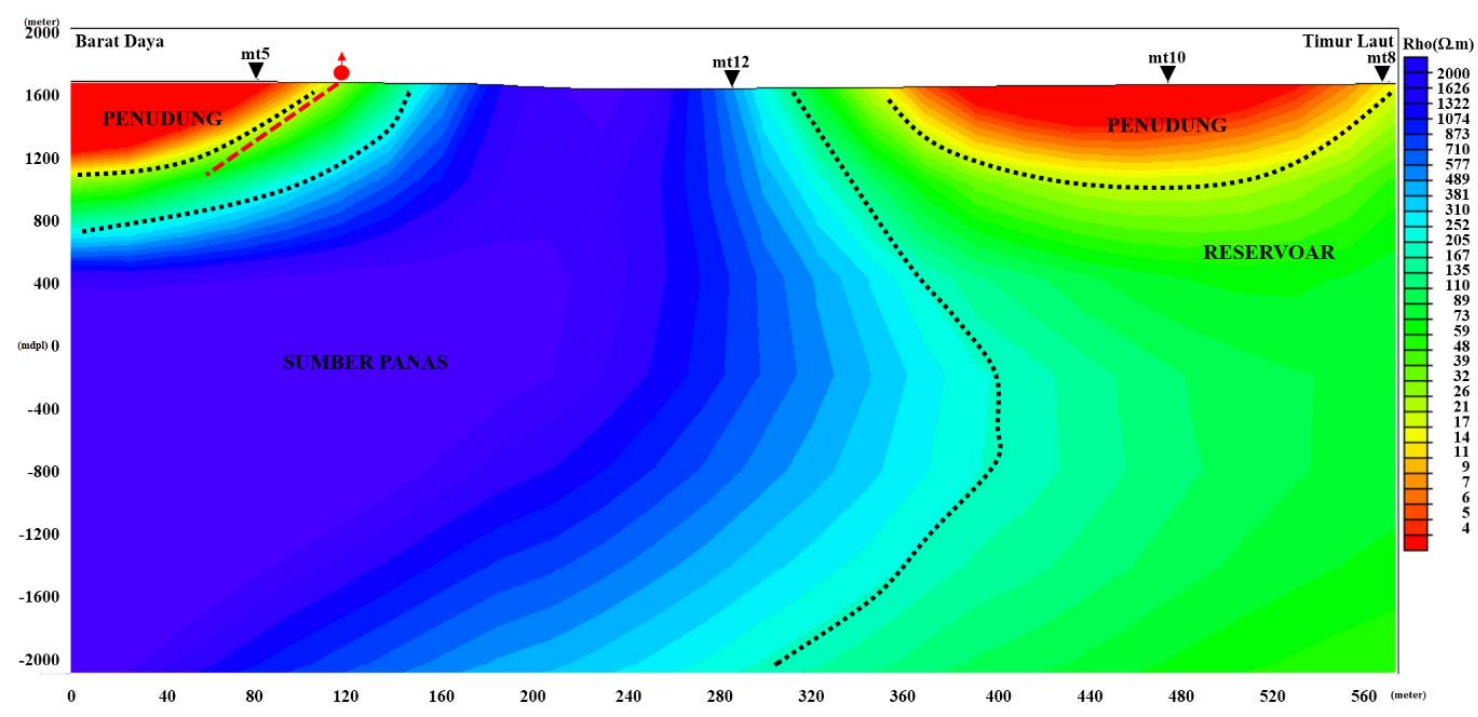

Gambar 6. Model Penampang 2D Lintasan 3 


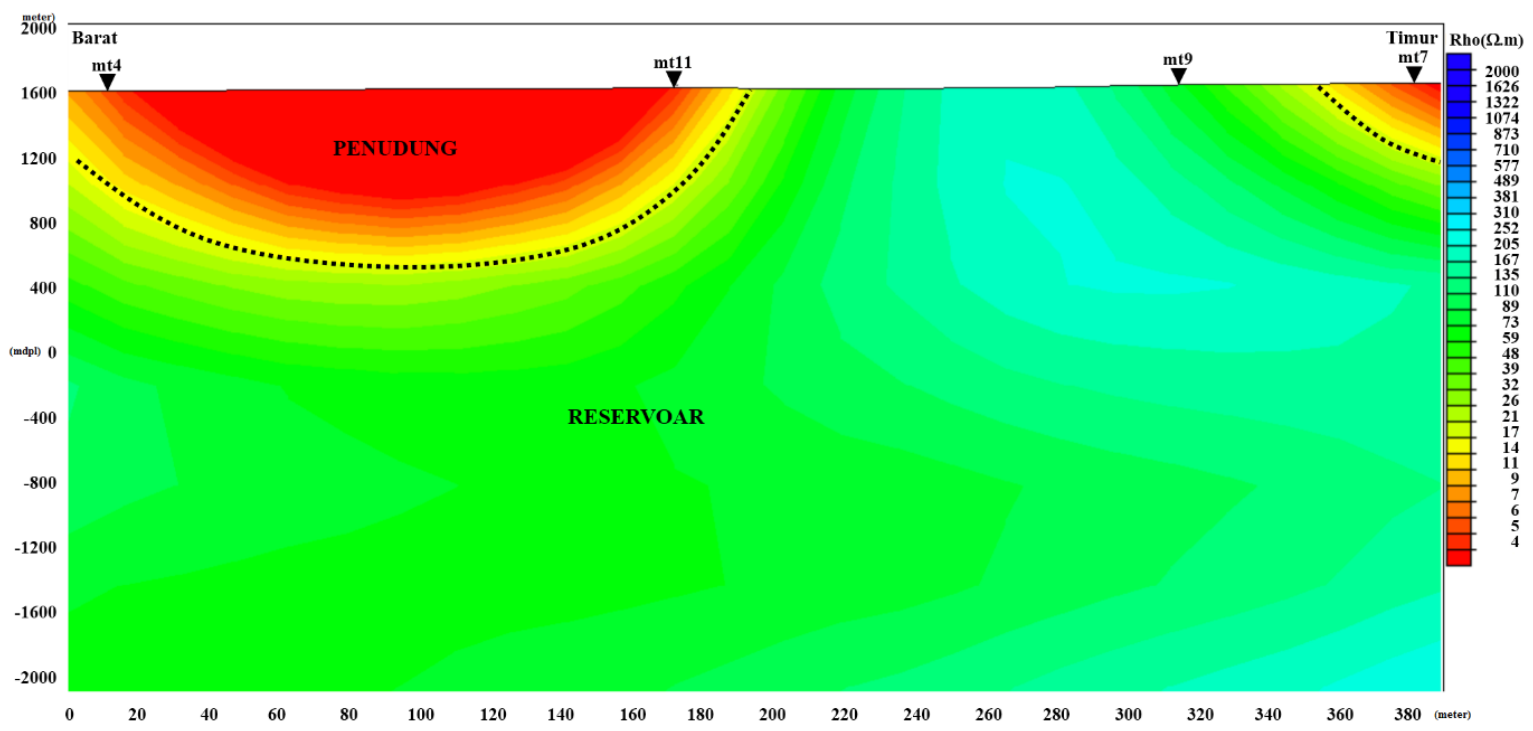

Gambar 7. Model Penampang 2D Lintasan 4

Lintasan 4 terdiri dari MT5, MT11, MT9 dan MT7. Hasil dari penampang lintasan 4 (Gambar 7) terdapat lapisan dengan nilai resistivitas rendah $(\leq 21 \Omega . \mathrm{m})$ yang muncul di permukaan hingga kedalaman 600 meter di arah barat dan terdapat juga di arah timur. Teridentifikasi juga lapisan yang memiliki nilai resistivitas sedang ( $21 \Omega . \mathrm{m}-167 \Omega . \mathrm{m})$, lapisan ini juga muncul di permukaan diduga terdapat retakan batuan pada wilayah ini. Nilai resistivitas tinggi tidak nampak pada lintasan ini, diduga nilai resistivitas tinggi berada pada kedalaman yang lebih dalam dibandingkan lintasan yang lainnya.

Model penampang lintasan 5 (Gambar 8) terdiri dari MT6, MT9 dan MT10. Pada penampang lintasan ini teridentifikasi lapisan yang memiliki nilai resisitivitas rendah $(\leq 21 \Omega$.m), sedang $(21 \Omega . m$ - $167 \Omega . m$ ) dan tinggi ( $\geq 167 \Omega . m$ ) yang tersebar merata pada semua titik pengukuran. Lapisan resisitivitas rendah muncul pada permukaan hingga kedalaman 1000 meter. Tepat di bawah lapisan resisitivitas rendah terdapat lapisan resisitivitas sedang dan diikuti oleh lapisan resisitivitas tinggi.

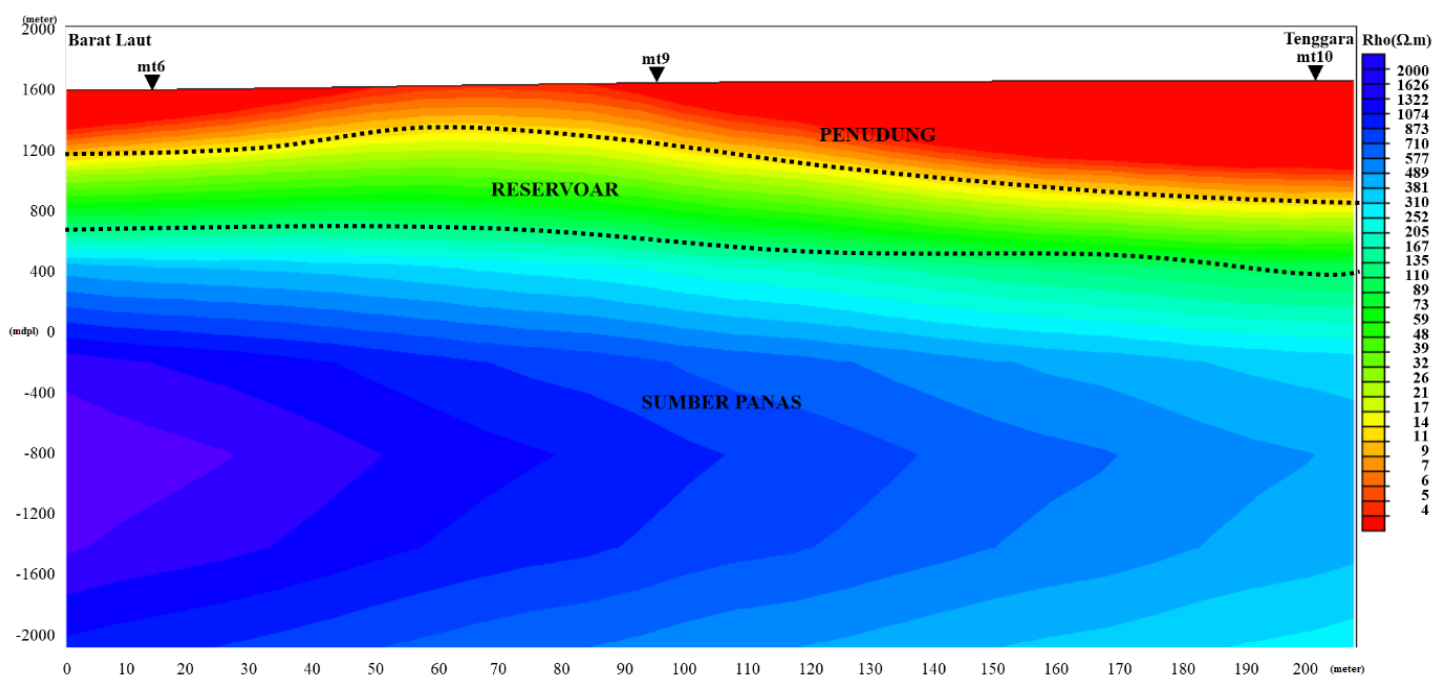

Gambar 8. Model Penampang 2D Lintasan 5 
Berdasarkan hasil penelitian diketahui bahwa rentang nilai resisitivitas di daerah Cangar berkisar antara $4 \Omega . \mathrm{m}-2000 \Omega . \mathrm{m}$. Lapisan dengan nilai resisitivitas rendah $(\leq 21 \Omega . \mathrm{m})$ diinterpretasikan sebagai lapisan penudung dengan keberadaan tingginya kandungan mineral lempung pada batuan [16]. Nilai resisitivitas rendah tersebut sebagai respon dari batuan yang teralterasi akibat adanya interaksi antara fluida panas dengan batuan di sekitarnya [17]. Lapisan penudung bersifat kedap air sehingga memiliki kemampuan mencegah keluarnya fluida panas yang terdapat di reservoar menuju permukaan. Lapisan yang memiliki nilai resisitivitas sedang (21 $\Omega . m-167 \Omega . m)$ biasanya berasosiasi dengan batuan yang berfungsi sebagai reservoar panas bumi. Reservoar panas bumi memiliki nilai resistivitas lebih tinggi dibandingkan lapisan penudung dikarenakan berkurangnya mineral lempung pada batuan penyusun [18]. Reservoar merupakan tempat terakumulasinya fluida pembawa panas yang bersifat permeabel [8]. Nilai resisitivitas tertinggi pada penampang hasil 2D inversi yaitu $\geq 167$ $\Omega$.m diduga sebagai lapisan sumber panas daerah panas bumi Cangar. Sumber panas berfungsi untuk memanasi fluida yang tersimpan di dalam reservoar melalui konveksi [8]. Ketiga lapisan tersebut merupakan sistem utama dari panas bumi.

Sebagai pendukung hasil dari penelitian ini, dikorelasikan dengan data PSDG dan penelitian sebelumnya (magnetik dan geolistrik). Berdasarkan data PSDG diketahui bahwa pada kompleks Arjuno-Welirang daerah yang memiliki nilai resistivitas rendah tersebar di dua lokasi yaitu salah satunya berada di sekitar panas bumi Cangar. Nilai resisitivitas lapisan tersebut yaitu $\leq 10 \Omega$.m yang diduga sebagai lapisan penudung. Di daerah panas bumi Cangar juga tersebar lapisan dengan nilai resisitivitas sedang yaitu $20 \Omega . m-100 \Omega$.m yang diduga sebagai lapisan reservoar. Berdasarkan data geologi, batuan penyusun lapisan reservoar adalah lava dan piroklastik. Selain itu terdapat juga lapisan yang memiliki nilai resistivitas tinggi yang diduga sebagai lapisan sumber panas. Sumber panas tersebut diduga berasal dari bawah kerucut Gunung Arjuno-Welirang [6].

Berdasarkan penelitian sebelumnya khusunya pada lintasan 1 dan lintasan 3 dimana arah lintasan ini sama dengan arah sayatan dari metode magnetik yaitu arah barat laut-tenggara dan barat-timur. Hasil penampang magnetik pada kedua sayatan tersebut diperoleh nilai suseptibilitas rendah yaitu 3,166 dan $-0,018$. Nilai suseptibilitas rendah tersebut diduga sebagai indikasi keberadaan potensi panas bumi daerah Cangar [9]. Batuan dalam sistem panas bumi memiliki magnetisasi lebih rendah dibandingkan dengan batuan sekitarnya melalui proses alterasi hidrotermal [7]. Batuan yang diduga menjadi batuan pembawa panas adalah basalt [9]. Air panas berasal dari pemanasan air bawah tanah oleh batuan basalt dan batuan lava dari batuan vulkanik Arjuno-Welirang [7]. Sedangkan berdasarkan metode geolistrik diketahui nilai resistivitas pembawa fluida panas yaitu $\leq 10 \Omega$.m. Terdapat lima lokasi manifestasi panas bumi yang berada di sekitar kolam pemandian air panas Cangar [10]. Berdasarkan hasil magnetotelurik pada penampang 2 dan 3 diketahui bahwa terdapat manifestasi air panas yang diduga berasal dari retakan batuan yang berada di sekitar kolam pemandian air panas yang ditandai dengan adanya terobosan nilai resistivitas sedang ke permukaan.

Air panas Cangar diduga dikontrol oleh patahan Cangar [7]. Akibat dari aktivitas patahan tersebut menyebabkan retakan atau rekahan pada batuan. Retakan batuan juga dapat berasal dari sifat fisik batuan itu sendiri yaitu salah satunya banyaknya mengandung pori [6]. Patahan dan retakan batuan diduga menjadi media keluarnya fluida panas yang berada di reservoar naik ke permukaan. Keberadaan patahan Cangar, rekahan batuan dan jenis air panas bikarbonat mengidentifikasikan bahwa daerah panas bumi Cangar diduga merupakan zona outflow. Sedangkan zona upflow diduga berada di bawah puncak Gunung Welirang yang berasosiasi dengan batuan andesit [19].

\section{Kesimpulan}

Dari hasil pengolahan 2D inversi data magnetotelurik diperkirakan adanya sistem panas bumi bumi di daerah Cangar dengan nilai resistivitas yang berbeda tiap lapisan, yaitu lapisan dengan nilai 
resistivitas rendah $(\leq 21 \Omega . \mathrm{m})$ yang diduga merupakan lapisan penudung, resistivitas sedang (21 $\Omega . \mathrm{m}$

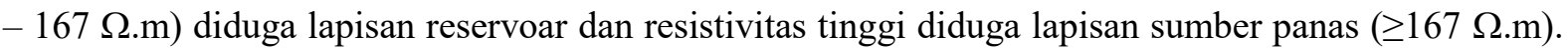
Pada area sistem panas bumi Cangar tersebut ternyata terdapat patahan Cangar dan beberapa retakanretakan batuan di sekitar manifestasi air panas. Hal tersebut menunjukkan bahwa daerah Cangar merupakan zona outflow.

\section{Ucapan Terimakasih}

Penulis menyampaikan terima kasih yang tak terhingga kepada semua pihak yang telah membantu. Penelitian ini sebagian didanai dari PTUPT No. Ristek Dikti No. : 063/SP2H/LT/DPRM/IV/2017. Ucapan terima kasih juga disampaikan kepada Direktur Agrotechno Park UB di Cangar dan Kepala Taman Hutan Raya R. Soeryo yang telah mengizinkan pengambilan data di lokasi, juga kepada teman-teman S1 Teknik Geofisika dan S2 Fisika-Geofisika yang telah membantu dalam pengambilan data pengukuran.

\section{Daftar Rujukan}

[1] S. Suryantoro, S. Dwipa, R. Ariati, dan S. Darma, (2005), Geothermal Deregulation and Energy Policy in Indonesia, Proceedings World Geothermal Congress.

[2] S. Broto dan T. T. Putranto, (2011) Aplikasi Metode Geomagnet Dalam Eksplorasi Panasbumi, Journal Teknik, vol. 32, no. 1, pp. 79-87.

[3] Kasbani, (2009), Sumber Daya Panas Bumi Indonesia: Status Penyelidikan, Potensi dan Tipe Sistem Panas Bumi, Prosiding Pusat Sumber Daya Geologi.

[4] M. N. Hadi, D. Kusnadi, dan S. Asep, (2010), Penyelidikan Terpadu Geologi, Geokimia dan Geofisika Daerah Panas Bumi Arjuno-Welirang, Kabupaten Mojokerto dan Malang, Provinsi Jawa Timur," Prosiding Pusat Sumber Daya Geologi.

[5] Y. Daud, F. Fahmi, W. A. Nuqramadha, D. M. Heditama, dan S. A. Pratama, (2015), 3Dimensional Inversion of MT Data over the Arjuno-Welirang Volcanic Geothermal System, East Java (Indonesia ), Proceeding World Geothermal Congress.

[6] Kementrian Energi dan Sumber Daya Mineral, (2017), Potensi Panas Bumi Indonesia, Jakarta, Ditjen EBTKE dan Badan Geologi.

[7] S. Maryanto, (2017), Geo Techno Park Potential at Arjuno-Welirang Volcano Hosted Geothermal Area, Batu, East Java, Indonesia (Multi Geophysical Approach), International Conference Global Resource Concervation.

[8] M. H. Dickson dan M. Fanelli, (2003), Geothermal Energy: Utilization and Technology. Paris: United Nations Educational, Scientific and Cultural Organization (UNESCO).

[9] A. Afandi, S. Maryanto, dan A. Susilo, (2012), Survei Geomagnetik di Daerah Cangar, Kota Batu , Jawa Timur untuk Mengkaji Potensi Panasbumi, Natural B, vol. 1, no. 3.

[10] F. Rakhmanto, S. Maryanto, dan A. Susilo, (2011), Tomografi Geolistrik Daerah Sumber Air Panas Cangar, Batu Kompleks Arjuno-Welirang, Natural B, vol. 1, no. 2, pp. 188-195.

[11] S. Maryanto, I. Karlina, L. Nur, C. N. Dewi, dan A. Rachmansyah, (2016), Integrated Resistivity and Ground Penetrating Radar Observations of Underground Seepage of Hot Water at Blawan-Ijen Geothermal Field, Inernational Journal Geophysics, vol. 2016.

[12] F. Simpson dan K. Bahr, (2005), Practical Magnetotelluric. New York: Cambridge University Press. 
[13] W. Xiao, (2004), Magnetotelluric Exploration in the Rocky Mountain Foothills, Alberta, University of Alberta.

[14] E. Erdoğan dan M. E. Candansayar, (2017), The conductivity structure of the Gediz Graben geothermal area extracted from 2D and 3D magnetotelluric inversion: Synthetic and field data applications, Geothermics, vol. 65, pp. 170-179.

[15] H. P. Hsu, (1995), Theory and Problems of Signals and Systems, New York, McGraw-Hill.

[16] S. Maryanto, C. N. Dewi, V. Syahra, A. Rachmansyah, J. H. Foster, A. Nadhir, dan D. R. Santoso, (2017), Magnetotelluric-Geochemistry Investigations of Blawan Geothermal Filed, East Java, Indonesia, Geosciences, vol. 7.

[17] A. Zarkasyi dan T. Rahadinata, (2015), Metode Penyelidikan Geofisika, Buku Panduan Penyelidikan Panas Bumi., pp. 59-90.

[18] H. Asaue, K. Koike, T. Yoshinaga dan S. Takakura, (2005), Magnetotelluric Resistivity Modeling for 3D Characterization Geothermal Reservoir in The Western Side of Mt. Aso, SW Japan, Journal of Applied Geophysiscs.

[19] A. P. Utama, A. Dwinanto, J. Situmorang, M. Hikmi, dan R. Irsamukhti, (2012), Green Field Geothermal Systems in Java, Indonesia, Proceeding ITB Geothermal Work. 